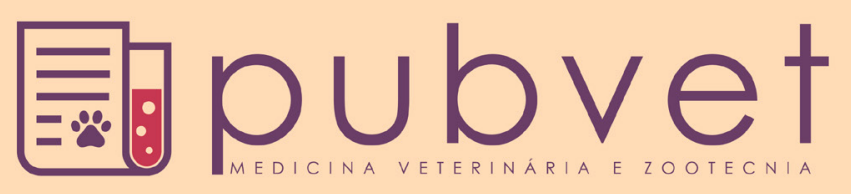

HTTP://DX.DOI.ORG/10.22256/PUBVET.V11N6.620-637

\title{
Contabilidade ambiental: Caracterização do passivo ambiental gerado pelo Lixão em Jussara - Goiás
}

\author{
Stephany Alves Pereira de Araújo ${ }^{1,}$ Graciele Araújo de Oliveira Caetano ${ }^{2}$, Pammela \\ Ribeiro Bonfim de Lima ${ }^{1,}$, Denise Gomes Barros Cintra ${ }^{3}$, Francillu Moura Leite ${ }^{1,}$ Nubia \\ Reis de Paulo ${ }^{1}$
}

${ }^{1}$ Bacharel em Ciências Contábeis, Faculdade de Jussara, FAJ, Jussara-GO.

${ }^{2}$ Doutoranda em Produção de Ruminantes. Universidade Federal de Goiás, UFG-EVZ, Goiânia-GO; Docente da Faculdade de Jussara, Jussara-GO.gracielecaetano@outlook.com

${ }^{3}$ Bacharel em Ciências Contábeis, Especialista em Gestão Empresarial e de Negócios. Coordenadora do curso de Ciências Contábeis - Faculdade de Jussara, FAJ, Jussara-GO.

RESUMO. Os problemas ambientais fazem parte da vivência humana a muitos anos e isso foi ocasionado pela extração desenfreada dos recursos naturais, e pelo descarte dos materiais considerados inservíveis ao uso e consumo da sociedade. A lei 12.305/10 dispõe que governo, empresas e sociedade atuem na gestão dos resíduos sólidos, já que o descarte dos resíduos em locais inadequados causa prejuízo tanto a sociedade quanto ao meio ambiente. O município de Jussara-GO enfrenta problemas para se adequar à referida lei. No estudo de campo, foi demonstrado como os passivos ambientais oriundos do lixão, resultado de eventos passados, porém com a responsabilidade no presente e como a liquidação se faz por meio da saída de recursos que possam gerar benefícios econômicos, pois o descarte do lixo afeta toda a região causando diversos problemas ambientais. A pesquisa mostra, por meio de fotos, os diversos materiais descartados no lixão da cidade de Jussara, como caixas de papelão, plásticos, garrafas PET e de vidro, pilhas, baterias, lâmpadas florescentes, dentre outros materiais que prejudicam o ar, solo e recursos hídricos. O leitor será convidado a conhecer, pela leitura desse artigo, como a questão ambiental tem efeito na economia através do estudo do passivo ambiental gerado pelo lixão.

Palavras chave: Destino de resíduos sólidos, lixão, passivo ambiental

\section{Environmental accountancy: Characterization of the environmental liability generated by dumpsite in Jussara - Brasil}

\begin{abstract}
Environmental problems are part of the human experience for many years due to the uncontrolled extraction of natural resources, and the disposal of materials considered being unserviceable to the use and consumption of society. Law 12.305/2010 provides that government, companies and society must act in the management of solid waste, since the disposal of waste in inappropriate places causes harm to both society and the environment. The municipality of Jussara-GO faces problems to comply this law. In this study, was demonstrated how the environmental liabilities arising from the dump, result of past events, but with the responsibility in the present and how the liquidation is done through the exit of resources that can generate economic benefits, since the trash disposal affects Throughout the region causing various environmental problems. The research shows, through photos, the various materials discarded in the Jussara city dump, such as cardboard boxes, plastics, PET and glass bottles, batteries, florescent bulbs, among other materials that harm air, soil and water resources. The reader will be invited to know, through reading this article, how the environmental issue has an effect on the economy through the study of the environmental liability generated by the dumpsite.
\end{abstract}


Keywords: Environmental liability, dumpsite, disposal of solid waste

\title{
Contabilidad ambiental: Caracterización de la responsabilidad ambiental generada por el vertedero en Jussara - Brasil
}

\begin{abstract}
RESUMEN. Los problemas ambientales son parte de la experiencia humana desde hace muchos años y esto fue causado por la extracción desenfrenada de los recursos naturales, y la eliminación de los materiales considerados inútiles para el uso y consumo de la sociedad. Ley 12.305 / 10 establece que el gobierno, las empresas y la sociedad operan en la gestión de residuos sólidos, como la eliminación de residuos en lugares inadecuados que afectan negativamente tanto a la sociedad y el medio ambiente. El municipio de JussaraGO se enfrenta a problemas para adaptarse a la Ley. En el campo de estudio, se demostró cómo pasivos ambientales procedentes del vertedero, a raíz de sucesos pasados, pero con responsabilidad en este y la liquidación se realiza a través de la salida de recursos que puede generar beneficios económicos debido a la eliminación de residuos afecta en toda la región que causa diversos problemas ambientales. La investigación muestra a través de fotografías, los diversos materiales de desecho en el vertedero de basura de la ciudad de Jussara, tales como cajas de cartón, plástico, PET y botellas de vidrio, baterías, lámparas fluorescentes, entre otros materiales que dañan el aire, el suelo y recursos hídricos. Se invita al lector a aprender mediante la lectura de este artículo, ya que los problemas ambientales tienen efecto en la economía a través del estudio pasivos ambientales generados por el vertedero.
\end{abstract}

Palabras clave: Pasivos ambientales, vertedero, eliminación de residuos sólidos

\section{Introdução}

A sociedade não sobreviveria sem os benefícios trazidos pelos recursos ambientais, desde matéria prima para suprir as necessidades humanas, à qualidade de vida proporcionada por um meio ambiente ecologicamente sadio.

O meio ambiente é um bem comum de todos, sendo dever de cada um a conscientização de preservação da natureza. A preservação dos recursos ambientais é uma questão inserida aos poucos na sociedade, pois a cada dia ela se depara com as crescentes consequências ambientais, devido à utilização dos recursos naturais de forma desenfreada e o descarte dos materiais considerados inservíveis para consumo.

O lixo quando descartado de forma inadequada pode trazer diversos problemas à sociedade e ao meio ambiente. A destinação correta é um desafio ao município de Jussara- GO, que assim como muitos pequenos municípios não possuem aterro sanitário e descarta 6.683 toneladas/ano de resíduos no lixão da cidade.

A Lei 12.305 criada em 2 de agosto de 2010, instituiu a Política Nacional dos Resíduos Sólidos, que possui como objetivo mudar o cenário de diversos municípios estipulando um prazo de 4 (quatro) anos, desde a promulgação da Lei para os municípios se adequarem a ela, tendo como pontos principais, a implantação de um aterro sanitário, a reciclagem e a logística reversa.

A realidade é que seis anos após a promulgação da Lei, o município de Jussara-GO ainda não conseguiu se adequar a ela. É necessário construir um aterro sanitário para um descarte correto dos resíduos e a implantação da coleta seletiva para os resíduos que possam ser reaproveitados ou reciclados, e assim reintegrados ao processo produtivo, voltando a ser matéria prima deixando de ser um acúmulo no lixão.

Em face à problemática apresentada, foi desenvolvido um estudo caracterizando os passivos ambientais gerados pelo lixão, evidenciando a urgência da implantação de um aterro sanitário. Neste contexto, o objetivo desse trabalho é caracterizar os passivos ambientais do lixão da cidade de Jussara.

\section{Revisão de literatura}

$\mathrm{O}$ homem vem extraindo os recursos naturais, para subsistência da espécie, mas principalmente para obtenção de riquezas. Com o aumento da população, cresceu o consumo, gradativamente surgiram diversas empresas oferecendo produtos que satisfação um mercado cada vez mais exigente. Com o aumento do consumo, consequentemente houve um aumentou do descarte dos materiais considerados inservíveis. 
Com o passar dos anos os consumidores estão mais exigentes, buscando consumir produtos de empresas que se preocupam com a preservação do meio ambiente. São empresas que exploram esse novo nicho de mercado, adotando em sua gestão, táticas como o marketing verde.

A contabilidade, tradicionalmente tem como função a mensuração da situação patrimonial e econômica da entidade, nesse contexto a contabilidade ambiental, tem como responsabilidade evidenciar o nível de conscientização da empresa, com gastos ou receitas provenientes da preservação ambiental.

\section{Contabilidade Ambiental}

As empresas responsáveis por extrair os recursos naturais para produzirem bens de consumo, produzem diversos resíduos, prejudiciais ao meio ambiente. "Do ponto de vista da contabilidade, o que se pode medir e fazer constar, nas demonstrações contábeis são os eventos e transações econômico-financeiros, que refletem a interação da empresa com o meio ambiente"(Ribeiro, 2006).

A contabilidade tendo como objeto o patrimônio das entidades é responsável por mensurar as receitas e os gastos provenientes da valoração dos recursos ambientais:

A contabilidade ambiental não é uma nova ciência, mas sim, uma segmentação da tradicional já, amplamente, conhecida. Adaptando o objetivo desta última, podemos definir como objetivo da contabilidade ambiental: identificar, mensurar e esclarecer os eventos e transações econômicofinanceiros que estejam relacionados com a proteção, preservação e recuperação ambiental, ocorridos em um determinado período, visando a evidenciação da situação patrimonial de uma entidade (Ribeiro, 2006).

A contabilidade ambiental é um desdobramento a mais da contabilidade tradicional, a fim de quantificar as transações econômico-financeiras, especificando gastos, ou receitas da atividade de preservação ambiental.

As empresas têm suas atividades operacionais normais e que em alguns casos, afetam o meio ambiente de forma direta ou indireta. As empresas devem desenvolver medidas para a proteção do meio ambiente, consequentemente melhorando sua imagem perante o governo e a sociedade, e principalmente evitando problemas legais futuros (Tinoco \& Kramer, 2011) complementam que:
Ultimamente os gastos e os custos/despesas das empresas em proteção ambiental, incluindo redução de poluição e de resíduos, monitorização da avaliação ambiental, impostos e seguros, têm aumentado rapidamente com a crescente e mais exigente regulamentação ambiental, decorrente da vigília crescente da sociedade.

A preocupação com o meio ambiente por parte da sociedade tem aumentado, e por parte do governo também, pois o poder público vem desenvolvendo mecanismos de proteção ao meio ambiente, por meio de leis mais severas contra os poluidores.

\section{Ativos Ambientais}

Para a contabilidade, o ativo representa benefícios econômicos futuros, como definido por Iudícibus (1998) onde o autor afirma que: "são todos os bens e direitos de propriedade e controle da empresa, que são avaliáveis em dinheiro e que representam benefícios presentes ou futuros para a empresa". No campo ambiental, dos ativos ambientais também se esperam benefícios econômicos em períodos futuros, como um conjunto de bens e direitos do meio ambiente, mostrando o desempenho em preservá-lo. Essas informações são demonstradas à parte das demonstrações contábeis, permitindo ao governo e a sociedade comparar tais informações (Ribeiro, $\underline{2006)}$.

Os ativos ambientais são desembolsos em bens e direitos, afim de evitar ou reduzir danos que as atividades causam ao meio ambiente. São classificados como ativos, se servirem de maneira durável à atividade da entidade; esses custos trazem benefícios econômicos, prolongando a vida útil, aumentando a segurança ou eficiência de outros ativos da entidade, e principalmente evitam uma contaminação ambiental (Tinoco and Kraemer, 2004).

\section{Passivo ambiental}

Para a contabilidade clássica, Iudícibus (1998) define passivo como"[...] evidencia toda a obrigação (dívida) que a empresa tem com terceiros; contas a pagar, fornecedores de matériaprima (a prazo), impostos a pagar, financiamentos, empréstimos etc.”. Nem sempre é possível pagar todas as obrigações a vista, sendo necessário para a empresa contrair dívidas com terceiros para dar continuidade as atividades da empresa. Já na Contabilidade Ambiental, (Tinoco and Kraemer, 2004) definem o passivo ambiental como, 
"surgem da posse e do uso [...] de uma série de espaços que compõem nosso meio ambiente, inclusive o ar que respiramos, e que de alguma forma estão sendo prejudicados, ou ainda pelo processo de geração de resíduos ou lixo industriais, de difícil eliminação". O passivo ambiental ocasiona um ar de algo negativo, frequentemente está associado às atividades industriais que agridem o meio ambiente, porém é de responsabilidade das empresas possuir mecanismos de proteção ao meio ambiente.

De acordo com Ribeiro (2006)os passivos ambientais são: "[...] referir aos benefícios econômicos ou aos resultados que serão sacrificados em razão da necessidade de preservar, proteger e recuperar o meio ambiente, $[\ldots]$ ou em decorrência de uma conduta inadequada em relação a estas questões".

A empresa conta com a obrigação de implantar em sua gestão, mecanismos capazes de evitar danos ao meio ambiente, porém ocorrem casos onde há intencionalmente, ou não, danos ambientais, oriundos das atividades humanas. Esses danos devem de qualquer forma ser corrigidos.

Segundo Ribeiro (2006) as obrigações são classificadas em: legais, justas e construtivas. Legais são em decorrência de contratos, legislação, penalidades ou algum outro instrumento imposto por lei, em virtude de um evento passado se adquire uma obrigação legal no presente. Justas: independentemente da lei, a empresa é guiada por fatores éticos e morais, se mostrando de fato preocupada com sua devida reputação. Construtivas: são os casos onde por iniciativa da empresa se propõe a cumprir as exigências legais, onde é cumprindo a exigência necessária e algo a mais.

Ribeiro conclui que o passivo ambiental "corresponde às obrigações relacionadas aos gastos ambientais incorridos pela empresa e que satisfaçam os critérios para reconhecimento como exigibilidade"

Quando há investimentos por parte da empresa em tecnologias que evitem ou minimizem os impactos causados pela atividade industrial, são classificados como ativos. Já os passivos ambientais, são quando, por algum motivo, a atividade empresarial trouxer consequências ao meio ambiente, devendo serem corrigidas para reduzir os impactos aos seres humanos e meio ambiente.

\section{Formas de mensuração do passivo ambiental}

O Passivo ambiental é reconhecido quando ocorre o fato gerador, gerando uma obrigação por parte da empresa que ocasionou esse passivo, adquirindo assim, o dever de reparar o dano causado ao meio ambiente. Esse detrimento ambiental precisa ser mensurado, porém quando o assunto é o meio ambiente, essa mensuração é difícil, pois são bens e diretos da sociedade, e muitas vezes seus impactos são sentidos após longos períodos.

Algumas vezes, a exigibilidade existe e a empresa possui os parâmetros para determinar ou estimar razoavelmente $o$ valor a ser desembolsado, classificando-o dentro do devido regime de competência. Em outros casos, a empresa precisa utilizar cálculos estimativos para fazer o reconhecimento do passivo. Portanto, todos os gastos para a manutenção do gerenciamento ambiental devem ser reconhecidos no período em que ocorrem e, da mesma forma, quando se toma conhecimento de que o meio natural sofreu impactos nocivos em decorrência do processo operacional, deve-se procurar imediatamente informações técnicas que subsidiem a determinação do valor da obrigação que já existe (Malafaia, 2004).

Para Tinoco and Kraemer (2004) a mensuração do passivo ambiental se dá por meio dos relatórios financeiros, se houver dificuldades na estimativa do valor, deverá ser provisionado um valor estimável, sendo que todos os detalhes da estimativa devem vir especificados nas notas explicativas. A mensuração do passivo se dá através dos:

Custos incrementais diretos que podem ocorrer com a reparação; Custos dos salários e encargos sociais aos trabalhadores vinculados ao processo de restauração ambiental; Obrigações de controle após a reparação dos danos ambientais; e Processo tecnológico à medida que seja provável que as autoridades públicas recomendem a utilização de novas tecnologias (Tinoco and Kraemer, 2004). Os custos acima citados devem ser quantificados, especialmente para demonstrar ao governo e toda sociedade que, independentemente de ter ocorrido o passivo ambiental, a empresa se preocupou em reparar os danos, pois a quantificação do valor é a prova dos fatos.

A empresa deve adotar uma postura ambientalmente correta, evidenciando as práticas de conservação e recuperação do meio ambiente. 
Alguns fatores influenciam na disposição da empresa em adotar práticas sustentáveis, como: cultura local - as pessoas físicas e jurídicas pressionam as empresas a aderir a gestão sustentável na entidade. Imposições legais órgãos reguladores impõem normas, que caso não seja cumprida, sujeitaram-se às sanções penais e administrativas. Empresas exportadoras - os importadores estão cada vez mais rigorosos, exigindo cuidado e evidenciação de ações relacionadas ao meio ambiente(

"Embora seja complexa, a mensuração das contas ambientais é fundamental para que a contabilidade as registre com valores confiáveis, procurando refletir a verdadeira posição em que a empresa se encontra com relação aos eventos ligados ao meio ambiente"(Costa, 2012).

Por se tratar de eventos que causam danos ao meio ambiente, principalmente em longo prazo, e indispensável para a contabilidade mensure os gastos ou despesas por parte da entidade, mostrando principalmente que a empresa se preocupa com os danos que ela irá causar ou causou ao meio ambiente.

\section{Gastos, custos e despesas ambientais}

Os gastos, custos e despesas ambientais são motivo de grande confusão por ter significado muito parecido, Santos et al. (2001) definem custos e despesas ambientais como:

Custos e despesas ambientais são gastos (consumo de ativos) aplicados direta ou indiretamente no sistema de gerenciamento ambiental do processo produtivo e em atividades ecológicas da empresa. Quando aplicados diretamente na produção, estes gastos são classificados como custo, e se forem aplicados de forma indireta são chamados de despesa.

Para Ribeiro (2006), despesas ambientais, são "todos os gastos envolvidos com o gerenciamento ambiental, consumidos no período e incorridos na área administrativa". Os custos ambientais são os gastos na área ambiental, ocasionando benefícios futuros para a sociedade, consequentemente resultando em um ambiente sadio, graças à conservação dos recursos naturais, "[...], porém não necessariamente refletirão expectativas de benefícios futuros para a entidade que incorreu nos gastos, mas apenas despesas do período"(Ribeiro, 2006).

Tanto os custos, quanto as despesas ambientais estão relacionadas com a proteção do meio ambiente, a procura da conservação ou diminuição do impacto da ação do homem. Quando há benefícios futuros e são classificados diretamente à produção, são identificados como custos, já os gastos sem benefícios futuros são classificados de forma indireta, considerado como despesa.

\section{Homem e consumismo}

\section{Sobrevivência vs. Ambição}

A agricultura sempre esteve presente na vida do homem, desde o início das civilizações; onde era necessário elaborar métodos para garantir a sobrevivência, desde táticas de caça, até o desenvolvimento de técnicas para o plantio da terra. Com o tempo os conhecimentos sobre agricultura e pecuária foram se aperfeiçoando, e devido ao espaço que as fazendas dispunham para o plantio das lavouras, grande quantidade dos habitantes se encontrava na área rural. Os produtos colhidos serviam para comercialização nos centros urbanos, base de troca com outros produtos ou serviços, ou simplesmente para a subsistência da família.

Com o decorrer dos anos houve uma migração das famílias rurais para as cidades "fenômeno que ficou conhecido pelo nome de êxodo rural" (Souza, 2010). O serviço do trabalhador do campo, muitas vezes requer um grande esforço físico, exposição ao sol durante longos períodos, falta de transporte, falta de equipamentos necessários para realizar tarefas diárias, devido a esses e outros fatores os pais de família foram em busca de uma melhor remuneração salarial, ensino de qualidade para as crianças e conforto.

Dias (2014) traz alguns problemas ambientais em consequência da industrialização:

Entre os muitos problemas ambientais que a industrialização trouxe estão: a alta concentração populacional, devido à urbanização acelerada; consumo excessivo de recursos naturais, sendo alguns não renováveis (petróleo e carvão mineral, por exemplo); contaminação do ar, do solo, das águas; desflorestamento entre outros. A industrialização trouxe à tona a ganância do homem, em busca de terras e poder, com isso deram início a primeira guerra mundial, que terminou em 1945, considerada a maior tragédia da história. Marcada por várias mortes e destruição de diversas cidades, os efeitos da guerra também refletiram no meio ambiente, mudando habitats, como fauna e flora (Dias, 2014). No ano de 1962, Raquel Carson, publicou um livro: Silent spring alertando a sociedade sobre os malefícios 
trazidos em decorrência do abuso de pesticidas químicos em lavouras. Os agricultores se opuseram contra à autora, pois devido à grande quantidade de pragas nas lavouras eram necessários os inseticidas. Como explicado por Araújo et al. (2016), a monocultura (processo de produção agrícola com apenas um tipo de produto sendo cultivado) era a melhor alternativa para obter grandes quantidades de produtos. Associadas a agrotóxicos (produtos desenvolvidos e utilizados na primeira e segunda guerra mundial como arma química para matar seres humanos), utilizados como "a gentes agrícolas" ou conhecidos como pesticidas, capaz de eliminar as pragas.

Carson sugeriu o combate às pragas por meio de controle biológico no qual fungos, bactérias e insetos combatem os parasitas das lavouras de forma natural, sem agredir o meio ambiente. Exemplificado melhor pela por Dinis (2016): a premissa básica do controle biológico é controlar as pragas agrícolas e os insetos transmissores de doenças a partir do uso de seus inimigos naturais, que podem ser outros insetos benéficos, predadores, parasitoides, e microrganismos, como fungos, vírus e bactérias. Trata-se de um método de controle racional e sadio, que tem como objetivo final utilizar esses inimigos naturais que não deixam resíduos nos alimentos e são inofensivos ao meio ambiente e à saúde da população. De forma natural o controle biológico diferente dos inseticidas, combate as pragas nas lavouras, não afeta os animais que por ali passarem e tão pouco os seres humanos que ingerirem os alimentos.

\section{A concentração populacional nos centros urbanos e as consequências ambientais}

À medida que as cidades foram se desenvolvendo, a população se concentrou nos grandes centros em busca de melhores condições de vida. A Tabela 1 com dados do IBGE, apresenta a evolução da migração da população rural para os centros urbanos.

Segundo a Tabela 1, em 1960 a população brasileira era de 70.992 .343 com $54 \%$ e mais da metade da população, se localizava na zona rural. Uma década depois a população vai para 94.508.583; porém o cenário se inverte, a população rural cai e a urbana vai para $55 \%$, dados que comprova o êxodo rural. As próximas décadas o crescimento urbano vai para $67 \%$ em $1980 ; 75 \%$ em 1991; 2000 em 81\%, e 84\% em 2010.
Tabela 1. População urbana e rural brasileira

\begin{tabular}{lcc}
\hline \multirow{2}{*}{ Ano } & \multicolumn{2}{c}{ População } \\
\cline { 2 - 3 } & Urbana & Rural \\
\hline 1960 & 32004817 & 38987526 \\
1970 & 52904744 & 41603839 \\
1980 & 82013375 & 39137198 \\
1991 & 110875826 & 36041633 \\
2000 & 137755550 & 31835143 \\
2010 & 160925792 & 29830007 \\
\hline
\end{tabular}

Fonte: Adaptado do IBGE, Censo Demográfico 1960, 1970, 1980, 1991, 2000 e 2010.

Analisando os dados apresentados na Tabela 2, especialmente no estado de Goiás, as estatísticas não são muito diferentes. $\mathrm{O}$ estado demorou duas décadas para a população rural migrar para as cidades. Em 1960 a população rural representava $66 \%$ caindo um pouco na próxima década para $53 \%$. Já em 1980 a uma forte migração para os centros urbanos, chegando a corresponder $67 \%$, na década seguinte o aumento é ainda maior e a população urbana vai para $80 \%$ em 1991. Crescendo $87 \%$ e $90 \%$ entre 2000 e 2010 respectivamente. A migração populacional não foi acompanhada pelos agentes públicos, não havendo planejamento das cidades: $\mathrm{O}$ que se deu em grande parte, repita-se pela migração da população rural para as cidades, culminando na centralização das pessoas nos grandes centros urbanos, principalmente nas cidades mais populosas: São Paulo, Rio de Janeiro, Salvador, Distrito Federal, Fortaleza e Belo Horizonte (Souza, 2010).

Tabela 2. População urbana e rural em Goiás

\begin{tabular}{lcc}
\hline \multirow{2}{*}{ Ano } & \multicolumn{2}{c}{ População } \\
\cline { 2 - 3 } & Urbana & Rural \\
\hline 1960 & 541469 & 1084907 \\
1970 & 1134242 & 1325765 \\
1980 & 2172965 & 1056254 \\
1991 & 3241119 & 771443 \\
2000 & 4390660 & 605779 \\
2010 & 5420714 & 583074 \\
\hline
\end{tabular}

Fonte: Adaptado do IBGE, Censo Demográfico 1960, 1970, 1980, 1991, 2000 e 2010.

O excesso de pessoas nos centros urbanos sem o devido planejamento populacional acarreta "a desorganização social, com carência de habitação, desemprego, problemas de higiene e de saneamento básico, modifica a utilização do solo e transforma a paisagem urbana" (Souza, 2010). A qualidade de vida é um bem-estar almejado por todos, por isso se faz justo unirmos para lutar por 
um ambiente saudável para esta e para as futuras gerações, pois os efeitos ao ser humano são poucos, comparados aos impactos a natureza, que por ordem natural tenta ao máximo reestabelecer o equilíbrio.

\section{Legislação ambiental}

A legislação brasileira é extensa, sendo uma das mais completas do mundo, por meio de leis, estabelece normas de conduta, assegurando a soberania da justiça no intuito de proteger o direito a todos, tanto para instituições públicas, privadas e principalmente aos cidadãos.

Em 31 de agosto de 1981por meio da Lei 6.938, foi instituída a Política Nacional do Meio Ambiente, tendo como objetivo "[...] a preservação, melhoria e recuperação da qualidade ambiental propícia à vida, visando assegurar, no País, condições ao desenvolvimento sócio econômico aos interesses da segurança nacional e à proteção da dignidade da vida humana [...]"

A Constituição Federal esclarece que todos têm direito ao meio ambiente e sendo uma obrigação de todos, tanto o poder público, como instituições privadas e a sociedade, o dever de preservá-lo, o não cumprimento da lei gera punição ao mesmo. A Constituição Federal em seu parágrafo $3^{\circ}$ do Art. 225 esclarece que:

Art. 225. Todos têm direito ao meio ambiente ecologicamente equilibrado, bem de uso comum do povo e essencial à sadia qualidade de vida, impondo-se ao Poder Público e à coletividade o dever de defendê-lo e preservá-lo para os presentes e futuras gerações. $\S 3^{\circ}$ As condutas e atividades consideradas lesivas ao meio ambiente sujeitarão os infratores, pessoas físicas ou jurídicas, a sanções penais e administrativas, independentemente da obrigação de reparar os danos causados.

Com o objetivo de proteger o meio ambiente a legislação ambiental no Brasil, existe no intuito de reduzir os impactos da ação do homem no meio ambiente, introduzindo normas e possíveis sansões a quem descumprir a lei.

A legislação ambiental deve ser conhecida e praticada, seu objetivo principal não é as penalidades sofridas a quem descumpre a lei, mas sim conscientizar as empresas e a sociedade, que os resíduos descartados no meio ambiente sem o devido tratamento ou reaproveitamento, acarretam diversos problemas ambientais, prejudicando principalmente as futuras gerações.
Em fevereiro de 1998 foi sancionada a lei 9.605 - Lei dos crimes ambientais "Dispõe sobre as sanções penais e administrativas derivadas de condutas e atividades lesivas ao meio ambiente, e dá outras providências". Os indivíduos que desobedecerem à lei sofrerão as penalidades legais. Em agosto de 2010, a lei 12.305 "Institui a Política Nacional de Resíduos Sólidos; altera a Lei no 9.605, de 12 de fevereiro de 1998; e dá outras providências". Trazendo novas diretrizes ao direito ambiental, a Política Nacional de Resíduos Sólidos divide a responsabilidade entre governo, empresas e sociedade, estabelecendo que todo resíduo deveria passar por um processo de reaproveitamento, descartando apenas os rejeitos "depois de esgotadas todas as possibilidades de tratamento e recuperação por processos tecnológicos disponíveis e economicamente viáveis, não apresentem outra possibilidade que não a disposição final ambientalmente adequada; antes da destinação final'’(BrasiL, 1988).

\section{Lei 12.305 - Política Nacional de Resíduos Sólidos}

Em 02 agosto de 2010 é regulamentada a lei 12.305 instituindo a Política Nacional de Resíduos Sólidos (PNRS), alterando e complementando alguns artigos da lei 9.605, de fevereiro de 1998 lei dos crimes ambientais. A lei $12.305 \mathrm{em}$ seu inciso XVI, art. $3^{\circ}$ define Resíduos Sólidos como: objeto, material ou substância decorrente de atividades humanas, porém rejeitado, pois seu consumo já não é considerado útil para a sociedade. Os resíduos em estado sólido ou semissólido não podem ter como destino final, corpos de água ou a rede pública, devendo ser analisado soluções tecnológicas disponíveis para uma correta destinação.

A lei define que todo objeto proveniente das atividades humanas, que consequentemente seria descartado em corpos de água, lixões ou aterros sanitários, devem ser analisadas soluções, como uso de tecnologias para o reaproveitamento ou descarte apropriado para cada tipo de material.

Segundo Fiorillo (2009) “[...] a palavra resíduo possui um sentido mais amplo e apresenta-se como termo mais técnico. Vê-se empregado como gênero do vocábulo lixo (lixo hospitalar, lixo industrial, lixo nuclear...)". A palavra lixo historicamente lembra algo que deve ser descartado, não sendo mais útil, já o termo resíduo de algo que ainda pode ser reaproveitado. 
O resíduo sólido é o material, a substância, o objeto ou bem descartado resultante de atividades humanas em sociedade, a cuja destinação final se procede, se propõe proceder ou se está obrigado (parte do inciso XV do art. $3^{\circ}$ ). Considerando que descartar é pôr de lado, vemos que a definição leva em conta o estado atual do bem, de cuja companhia nos desfaz. Não se leva em conta se o bem descartado é útil ou não. (Machado, 2014).

É essencial frisar que resíduo sólido não é o mesmo que rejeito, conforme Art. $3^{\circ}$ inciso XV da PNRS é considerado rejeito, "depois de esgotadas todas as possibilidades de tratamento e recuperação por processos tecnológicos disponíveis e economicamente viáveis, não apresentam outra possibilidade que não a disposição final ambientalmente adequada".

Costumamos generalizar tudo como lixo, porém há uma separação, onde resíduo é todo material proveniente das atividades humanas, como: comercial, industrial, agrícola, hospitalar, de prestação de serviços, de varrição e de lodos do sistema de tubulação de água. Ao se questionar sobre os resíduos, é essencial analisarmos se há tecnologias disponíveis para o reaproveitamento, e apenas após terem esgotado todas as possibilidades de tratamento é que os restantes são classificados como rejeitos, necessitando obrigatoriamente ter uma disposição final ambientalmente adequada.

A lei PNRS traz no art. $3^{\circ}$ incisos VII e VIII a destinação e disposição final: VII - destinação final ambientalmente adequada: envolve a reciclagem, compostagem, recuperação ou reaproveitamento dos resíduos, essas destinações e outras dispostas pelos órgãos competentes resguarda o direito à saúde e segurança pública, e principalmente diminuindo os efeitos negativos do meio ambiente.

$\mathrm{O}$ ponto essencial da destinação final ambientalmente adequada é inserir os materiais que podem ser aproveitados no processo industrial. VIII - disposição final ambientalmente adequada: destina os rejeitos a aterros, respeitando o regulamento específico, preservando o direito a saúde e segurança pública e reduzindo as consequências ao meio ambiente.

Vale ressaltar, que o inciso XVI - Resíduo Sólido, e inciso VII - destinação final ambientalmente adequada, estão interligados. Como no inciso XV - Rejeito está interligado com o inciso VIII - disposição final ambientalmente adequada, deixando bem claro que a disposição deve ser feita em aterros.

\section{Política Nacional dos Resíduos Sólidos - Aspectos relevantes}

A lei 12.305/10 mostra inúmeras definições, princípios e objetivos, dividindo a responsabilidade entre geradores, consumidores e poder público, ficando responsáveis as pessoas jurídicas ou físicas, direta ou indiretamente ligadas à geração dos resíduos, ficando comprometidos a desenvolver ações para o gerenciamento dos resíduos com o intuito de minimizar os impactos que a atividade industrial causa ao meio ambiente.

\section{Responsabilidade compartilhada}

A lei que instituiu a política nacional dos resíduos sólidos gera ênfase na responsabilidade compartilhada pelo ciclo de vida dos produtos e a logística reversa, inserindo a ideia de que as empresas podem utilizar materiais antes descartados, como matéria prima para produção de novos produtos, usando o conceito de reaproveitamento, reciclagem e principalmente reduzindo a quantidade de lixo enviado a lixões, aterros controlados ou aterros sanitários. Em seu Art. $30^{\circ}$ esclarece sobre a responsabilidade compartilhada pelo ciclo de vida os produtos, devendo ser implementada por importadores, fabricantes, comerciantes dos consumidores e titulares dos serviços público de limpeza urbana e de manejo de resíduos sólidos.

Distribuindo as responsabilidades entre os distribuidores, fabricantes, importadores e comerciantes se tornam mais fácil alcançar o objetivo de moderar os impactos que a atividade industrial causa ao meio ambiente. Seguindo o conceito do Art. $9^{\circ}$ da PNRS, onde prioriza a gestão e gerenciamento dos resíduos sólidos, na seguinte ordem: "não geração, redução, reutilização, reciclagem, tratamento dos resíduos sólidos e disposição final ambientalmente adequada dos rejeitos".

Em seu Art. 30 a PNRS definem os objetivos da responsabilidade compartilhada em: I elaborar técnicas sustentáveis na gestão empresarial; II incorpora na gestão da empresa o aproveitamento dos resíduos, na sua cadeia produtiva ou em outras cadeias produtivas; III diminuir a produção de resíduos; IV utilizar insumos que agride menos o meio ambiente; V estimulara produção e a utilização de produtos provenientes de materiais 
reciclados e recicláveis; VI incentivar para que as atividades produtivas conquistem o máximo de eficiência e sustentabilidade; VII estimular a responsabilidade socioambiental por meio de boas práticas.

A responsabilidade compartilhada divide a responsabilidade, entre poder público e empresas privadas que devem se conscientizar e adotar métodos de estratégias sustentáveis, na gestão da empresa, tentando impedir seu impacto ao meio ambiente.

\section{Logística reversa}

A lei 12.305 em seu artigo Art. 33 estabelece a implantação do sistema de logística reversa, para fabricantes, importadores, distribuidores e comerciantes, os quais devem retornar os produtos após o uso dos consumidores, não dependendo do serviço público, os seguintes produtos: I Agrotóxicos, e outros produtos cujo os resíduos constitua risco ao meio ambiente ,II -baterias e pilhas; III - pneus; IV -embalagens e resíduos de óleos lubrificantes; V - Lâmpadas fluorescentes e VI - eletroeletrônicos e seus componentes.

Os produtos acima listados pela lei geram riscos graves ao meio ambiente se descartados de forma incorreta. Produtos que seriam descartados inadequadamente no meio ambiente são reaproveitados, reparados ou descartados, no processo da logística reversa. Onde após o uso pelo consumidor, é retornado para o processo industrial, diminuindo a quantidade de resíduos que teriam destinação imprópria, destinando a um descarte ambientalmente correto.

O Art. 32 estabelece que as embalagens devam ser produzidas com produtos que podem ser reutilizados ou reciclados. Em seu parágrafo $3^{\circ}$ do Art. 33 da PNRS, específica algumas exigências estabelecidas entre o setor empresarial e o poder público, responsabilizando distribuidores, importadores, fabricantes e comerciantes, também introduzir na sua gestão: I - adquirir produtos ou embalagens usadas; II- Possibilitar postos para entregar os resíduos recicláveis ou reutilizáveis e III - fechar parceria com associações ou cooperativas de catadores de materiais recicláveis e reutilizáveis. A lei também estabelece regra os consumidores após o uso dos produtos, fazer a devolução dos produtos ou embalagens aos comerciantes ou distribuidores.

Em seu Art. 47 são listadas as proibições de destinação ou disposição final dos resíduos ou rejeitos: I -lançar em quaisquer corpos hídricos; II- a céu aberto, com exceção os resíduos de mineração; III - queima a céu aberto exceto se houver licença para essa finalidade; IV - outras formas descritas pelo poder público.

O inciso II do Art. 47 proíbe o descarte dos rejeitos ou resíduos a céu aberto, e no inciso III proíbe a queimada a céu aberto, casos que ocorrem em diversas cidades brasileiras. Mas logo em seguida, no Parágrafo $1^{\circ}$ do Art. 47, abre exceções: “§ $1^{\circ}$ Quando decretada emergência sanitária, a queima de resíduos a céu aberto pode ser realizada, desde que autorizada e acompanhada pelos órgãos competentes do SISNAMA, do SNVS e, quando couber, do SUASA".

Desde a data da publicação da lei os municípios brasileiros já tiveram o prazo de seis anos para se adequar a Lei 12.305, mas como no Art. 47 proíbe e abre exceção, para o descarte dos resíduos e de certa forma tranquiliza os municípios, a se adequarem a Lei. Em seu Art. 51, da PNRS esclarece:

Art. 51 Sem prejuízo da obrigação de, independentemente da existência de culpa, reparar os danos causados, a ação ou omissão das pessoas físicas ou jurídicas que importe inobservância aos preceitos desta Lei ou de seu regulamento sujeita os infratores às sanções previstas em lei, em especial às fixadas na Lei $\mathrm{n}^{\circ} 9.605$, de fevereiro de 1998, que "dispõe sobre as sanções penais e administrativas derivadas de condutas e atividades lesivas ao meio ambiente, e dá outras providências", e em seu regulamento.

Caso o indivíduo, sendo pessoa física ou jurídica descumpra o regulamento de condutas e exerça atividades que prejudiquem o meio ambiente, imposto na Lei 12.305 , sofrerá as sanções previstas na Lei 9.605, independente de culpa, terá que reparar ou tentar reduzir ao máximo os danos causados ao meio ambiente.

Por fim a Lei 12.305 em seu Art. 54 "a disposição final ambientalmente adequada dos rejeitos, observado o disposto no $\S 1^{\circ}$ do art. $9^{\circ}$, deverá ser implantada em até 4 (quatro) anos após a data de publicação desta lei". A implantação de projetos como disposto no art. $9^{\circ}$ de não geração, redução, reutilização, reciclagem ou tratamento dos resíduos sólidos, para finalmente destinar os rejeitos ao aterro sanitário, tinha o prazo de quatro anos, vencidos em 2014. Desde então já se passaram dois anos do prazo máximo que a lei estabeleceu para as prefeituras se adequarem a 
Lei, mas essa ainda é uma realidade distante para diversos municípios.

\section{Classificação dos resíduos sólidos}

De acordo com a Lei 12.305/10 que instituiu a Política Nacional dos Resíduos Sólidos, estabelecendo em seu artigo $13^{\circ}$ as modalidades dos resíduos, classificando os quanto à origem, contando com 11 (onze) espécies de resíduos. A seguir será exemplificada cada modalidade do artigo $13^{\circ}$ da referida Lei.

\section{- Resíduos domiciliares}

Em seu artigo $13^{\circ}$ da Lei 12.305/10. Inciso I, alínea ' $a$ '. Resíduos Domiciliares são definidos como: "Para os efeitos dessa lei, os resíduos sólidos têm a seguinte classificação: I - quanto à origem: resíduos domiciliares: os originários de atividades domésticas em residências urbanas".

São os resíduos provenientes das atividades em residências urbanas, composto por resíduos secos e úmidos (conhecido também como orgânico). O lixo orgânico deve ser separado do seco, pois cada um tem uma destinação e um reaproveitamento diferente, o lixo orgânico quando descartado de forma inadequada, produz o chorume (líquido de coloração escura e cheiro forte) prejudicial para a natureza e seres humanos, já o lixo seco pode ser reaproveitado ou reutilizado no processo industrial.

\section{- Resíduos secos}

Definem-se como resíduos secos, as embalagens fabricadas a partir de papel, plástico, vidros e metais, que estão presentes no cotidiano do homem durante a aquisição ou venda de produtos. Os produtos necessitam de uma das embalagens acima citadas para melhor comodidade no guardar, na conservação e no transporte.

Desde o início do processo de colheita, armazenamento, transporte até a venda do produto, são utilizadas diversas embalagens que na maioria das vezes serão descartadas de forma incorreta no meio ambiente. Um bom exemplo disso se dá quando adquirimos um produto no supermercado, esse produto já se encontra em uma embalagem, e para levarmos esse mesmo produto é necessária uma sacola, indispensável para o transporte até a residência.

Alguns supermercados já adotaram o sistema de sacolas reutilizáveis e distribuem essas sacolas aos clientes de forma gratuita. A maior adaptação está sendo por parte dos consumidores em se tonarem conscientes, pois as sacolas plásticas muitas vezes eram utilizadas no armazenamento de produtos utilizados na cozinha e banheiro, porém sua destinação final acaba sendo o lixo, passando vários anos até se decompor.

\section{- Resíduo orgânico}

Decorrente de restos de alimentos que a população ou a indústria não considera útil para consumo, o lixo orgânico na maioria das vezes é descartado de forma incorreta.

A melhor solução para sanar o problema dos resíduos orgânicos continua sendo o reaproveitamento, pois aqueles que não são tratados adequadamente constituem uma ameaça para a saúde pública se jogados em lixões a céu aberto, estes trarão problemas também ao solo, ar, água. Já para os inorgânicos a reciclagem a melhor solução, já que os mesmos demoram muito tempo para se decompor (Araújo et al. 2016).

O lixo orgânico quando descartado de forma imprópria, causa impacto ao meio ambiente, como geração de gases de mau cheiro, chorume, diversos animais e micro-organismos que podem prejudicar a saúde da população (Araujo et al., 2016) O lixo orgânico conta com a vantagem de se decompor facilmente, não significando que esse resíduo não vá degradar o meio ambiente, pois mesmo sendo dissolvido mais rápido pela natureza, sem o devido tratamento, esse resíduo pode vir contaminar, à água, o solo, sem mencionar as inúmeras doenças provenientes das bactérias que se aglomeram.

\section{- Resíduos de limpeza urbana}

Em seu artigo $13^{\circ}$ da Lei 12.305/10. Inciso I, alínea 'b', Resíduos de limpeza urbana são definidos como: "os originários da varrição, limpeza de logradouros e vias públicas e outros serviços de limpeza urbana".

Os centros urbanos concentram um grande número de pessoas circulando, e inconscientemente e até conscientemente descartam o lixo no meio da rua. Sem perceber que um simples papel de balinha, descartado em local impróprio pode prejudicar o meio ambiente, sem contar o aspecto de imundície que emite na cidade.

As prefeituras muitas vezes não possuem um programa junto aos moradores, para conscientizar a população dos danos que a ação humana causa ao meio ambiente, pois estão desrespeitando o 
direito do próximo em habitar num ambiente sadio.

\section{- Resíduos sólidos urbanos}

No artigo $13^{\circ}$ da Lei $12.305 / 10$. Inciso I, alínea 'c' define Resíduos sólidos urbanos como: "resíduos sólidos urbanos: os englobados nas alíneas "a" e "b". São resíduos decorrentes de domicílios e de limpeza urbana. As atividades industriais, o comércio, as residências, produzem lixo todos os dias, em grande quantidade.

Fatores como aumento na renda e crescimento populacional eleva o índice de lixo produzido. Um bom exemplo: com uma renda maior, o indivíduo irá consumir mais, consequentemente a indústria e o comércio terão maior demanda de mercadorias, produzindo em maior escala, e substituindo produtos que poderiam ser reaproveitados, por novos, excluindo os produtos velhos. Essa proporção aumenta com o crescimento populacional.

- Resíduos de estabelecimentos comerciais e prestadores de serviços

Em seu artigo $13^{\circ}$, a Lei $12.305 / 10$, Inciso I, alínea 'd' define os Resíduos de estabelecimentos comerciais e prestadores de serviços como: "os gerados nessas atividades, excetuados os referidos nas alíneas "b", “e”, "g”, "h" e “j”.

Esse inciso exclui as alíneas: "b" resíduos de limpeza urbana; "e" resíduos dos serviços públicos de saneamento básico; "g" resíduos de serviços de saúde; "h" resíduos da construção civil; "J" resíduos de serviços de transportes.

- Resíduos dos serviços públicos de saneamento básico

Em seu artigo $13^{\circ}$ da Lei $12.305 / 10$. Inciso I, alínea 'e' Resíduos dos serviços públicos de saneamento básico, engloba quase todas as atividades, exceto os referidos na alínea "c".

A alínea "c" em por sua vez, engloba a alínea "a" resíduos domiciliares e alínea "b" resíduos de limpeza urbana. Como citado acima onde a alínea "e" dos resíduos dos serviços públicos de saneamento básico exclui a alínea "c", automaticamente exclui as alíneas "a" e "b".

\section{- Resíduos industriais}

No artigo $13^{\circ}$ da Lei $12.305 / 10$. Inciso I, alínea ' $\mathrm{f}$ '. Resíduos industriais são definidos como "os gerados nos processos produtivos e instalações industriais".
As empresas fabricam uma elevada quantidade de resíduos, vários desses resíduos trazem inúmeros prejuízos à saúde humana e da natureza, por isso um controle eficiente por parte do poder público assegura o direto a um meio ambiente sadio a todos.

- Resíduos de serviços de saúde

Em seu artigo $13^{\circ}$ a Lei 12.305/10. Inciso I, alínea ' $\mathrm{g}$ '. Resíduos de serviços de saúde são definidos como: "os gerados nos serviços de saúde, conforme definido em regulamento ou em normas estabelecidas pelos órgãos do SISNAMA e do SNVS".

\section{- Resíduos da construção civil}

Em seu artigo $13^{\circ}$ a Lei 12.305/10. Inciso I, alínea ' $h$ ': Resíduos da construção civil são definidos como: "os gerados nas construções, reformas, reparos e demolições de obras de construção civis incluídas os resultantes da preparação e escavação de terrenos para obras civis".

As maiores quantidades dos resíduos da construção civil são: tijolos, telhas, concreto, dentre outros que podem deixar de ser um acumulo, é serem reaproveitados em outros processos produtivos, como na terraplanagem nivelando o solo, outros resíduos em menor proporção também compõem essa classificação, como os plásticos, metais, madeiras, vidros dentre outros que também podem se compor em outros processos produtivos.

\section{- Resíduos agro-silvopastoris}

Em seu artigo $13^{\circ}$ a Lei 12.305/10. Inciso I, alínea 'i': Resíduos agro-silvopastoris são definidos como: "os gerados nas atividades agropecuárias e silviculturas, incluindo os relacionados a insumos utilizados nessas atividades".

Nas grandes fazendas e possível notar os restos de fezes dos animais, e embalagens usadas de produtos veterinários, ambos os resíduos devem ser tratados ou reaproveitados corretamente, para não vir prejudicar o meio ambiente.

\section{- Resíduos de serviços de transportes}

Em seu artigo $13^{\circ}$ da Lei 12.305/10. Inciso I, alínea 'j'. Resíduos de serviços de transporte são definidos como: "os originários de portos, aeroportos, terminais alfandegários, rodoviários e ferroviários e passagens de fronteira". 


\section{- Resíduos de mineração}

Em seu artigo $13^{\circ}$ a Lei 12.305/10. Inciso I, alínea ' $k$ ': Resíduos de mineração são definidos como: "os gerados na atividade de pesquisa, extração ou beneficiamento de minérios".

\section{- Resíduos perigosos}

Em seu artigo $13^{\circ}$ da Lei 12.305/10. Inciso II, alínea 'a' Resíduos perigosos são definidos como: "aqueles que, em razão de suas características de inflamabilidade, corrosividade, reatividade, toxicidade, patogenicidade, carcinogenicidade, teratogenicidade e mutagenicidade, apresentam significativo risco à saúde pública à qualidade ambiental, de acordo com lei, regulamento ou norma técnica”. Alínea 'b' resíduos não perigosos são definidos como: “ aqueles não enquadrados na alínea 'a'.

\section{Questão dos resíduos sólidos urbanos no Brasil por estados}

Segundo pesquisa realizada pela Abrelpe (Associação Brasileira das Empresas de Limpeza Pública e Resíduos Especiais), representante da ISWA International Solid Waste Association no Brasil.
A geração dos Resíduos Sólidos Urbanos (RSU) no Brasil em 2014 foi de aproximadamente 78,6 milhões de toneladas de lixo produzido por ano. Tendo um aumento de $2,90 \%$ em relação a 2013. Já o lixo coletado, representa mais de $90 \%$ em relação ao lixo gerado em 2014. Esse lixo é recolhido por prestadores de serviços de limpeza urbana a serviço do poder público.

Mas como nem todos os municípios brasileiros contam com aterros sanitários ou aterros controlados, consequentemente todo esse lixo tem como destinação, lixões a céu aberto, eliminando todo esse lixo por meio de queima, produzindo uma grande quantidade de $\mathrm{CO}^{2}$.

Conforme a Tabela 3. Em 2014, os resíduos sólidos urbanos representavam um total de 215.297 toneladas de lixo ao dia. A região Centro Oeste conta com 15.219.608 habitantes, sendo a região com a menor quantidade de indivíduos, gerando 16.948 toneladas de RSU por dia, um índice de $1,114 \mathrm{Kg}$ de RSU por habitante ao dia. A quantidade de $\mathrm{kg} / \mathrm{hab} / \mathrm{dia}$, da região centro oeste, só perde para a região Sudeste com: 1,239 $\mathrm{kg} / \mathrm{hab} / \mathrm{dia}$. Porém a região Sudeste conta com um número maior de habitantes, sendo a mais populosa dentre as cinco regiões.

Tabela 3. Quantidade (kg/habitante/dia) - resíduos sólidos urbanos gerados

\begin{tabular}{ccccc}
\hline & \multicolumn{2}{c}{2013} & & 2014 \\
\cline { 2 - 5 } Regiões & $\begin{array}{c}\text { RSU. Gerado (ton. /dia) } \\
\text { Índice (kg/hab./dia) }\end{array}$ & População total & RSU gerado (ton/dia) & Índice (kg/hab/dia) \\
\hline Norte & $15.169 / 0,892$ & 17.261 .983 & 15.413 & 0,893 \\
Nord. & $53.465 / 0,958$ & 56.186 .190 & 55.177 & 0,982 \\
Centro Oeste & $16.636 / 1,110$ & 15.219 .608 & 16.948 & 1,114 \\
Sudeste & $102.088 / 1,209$ & 85.115 .623 & 105.431 & 1,239 \\
Sul & $21.922 / 0,761$ & 29.016 .114 & 22.328 & 0,770 \\
Brasil & $209.280 / 1,041$ & 202.799 .518 & 215.297 & 1,062 \\
\hline
\end{tabular}

Fonte: adaptado da pesquisa ABRELPE e IBGE 2013 e 2014.

\section{Iniciativas de coleta seletiva de resíduos sólidos urbanos no Brasil por estados}

A lei $\mathrm{n}^{\circ}$ 12.305/10 estabelece a Política Nacional de Resíduos Sólidos "como a coleta de resíduos sólidos previamente separados de acordo com a sua constituição e composição, devendo ser implementada por municípios como forma de encaminhar as ações destinadas ao atendimento do princípio da hierarquia na gestão de resíduos".

Os municípios já deveriam ter adotado em sua gestão, desde 2014. Em uma análise englobando todos os estados em 2014 a média é de que mais de $64 \%$ dos municípios brasileiros, com iniciativa de coleta de lixo. Porém, se analisarmos a realidade da região Centro Oeste, esse dado se inverte, e $62 \%$ dos municípios não tem iniciativas de coletas seletivas, em seguida a região Nordeste tem um índice de $57 \%$ de municípios que não se adequaram, sendo as duas regiões com o pior índice de iniciativa de coleta de lixo (Tabela 4) 
Tabela 4 - Municípios com Iniciativas de Coleta Seletiva

\begin{tabular}{|c|c|c|c|c|c|c|c|c|c|c|c|c|}
\hline \multirow[b]{2}{*}{$\underline{\text { Região }}$} & \multicolumn{2}{|c|}{ Norte } & \multicolumn{2}{|c|}{ Nordeste } & \multicolumn{2}{|c|}{ Centro Oeste } & \multicolumn{2}{|c|}{ Sudeste } & \multicolumn{2}{|c|}{ Sul } & \multicolumn{2}{|c|}{ BRASIL } \\
\hline & 2013 & 2014 & 2013 & 2014 & 2013 & 2014 & 2013 & 2014 & 2013 & 2014 & 2013 & 2014 \\
\hline Sim & 223 & 239 & 725 & 767 & 158 & 175 & 1378 & 1418 & 975 & 1009 & 3459 & 3608 \\
\hline Não & 227 & 211 & 1069 & 1027 & 309 & 292 & 290 & 250 & 216 & 182 & 2111 & 1962 \\
\hline Total & \multicolumn{2}{|c|}{450} & \multicolumn{2}{|c|}{1794} & \multicolumn{2}{|c|}{467} & \multicolumn{2}{|c|}{1668} & \multicolumn{2}{|c|}{1191} & \multicolumn{2}{|c|}{5570} \\
\hline
\end{tabular}

Pesquisa ABRELPE (2013 e 2014).

Resíduos Sólidos Urbanos - Brasil - Região Centro Oeste

A região Centro Oeste conta com 467 municípios e o Distrito Federal, gerando em 2014 a quantia de 16.948 toneladas/dia de RSU, das quais $93,4 \%$ foram coletadas. Os índices indicam um crescimento de $2,2 \%$ no total coletado e aumento de $1,9 \%$ na geração de RSU em relação ao ano anterior (Tabela 5).

Tabela 5. Coleta e Geração de RSU na Região Centro Oeste

\begin{tabular}{c|c|c|c|c|c|c|c}
\hline \multicolumn{2}{l|}{ Geração de resíduos sólidos urbanos } & \multicolumn{3}{l}{ Coleta de resíduos sólidos urbanos } \\
\hline \multicolumn{2}{l|}{} & \multicolumn{2}{c|}{$\mathrm{kg} / \mathrm{hab} / \mathrm{dia}$} & \multicolumn{2}{c}{ ton/dia } & \multicolumn{2}{c}{$\mathrm{kg} / \mathrm{hab} / \mathrm{dia}$} \\
\hline 2013 & 2014 & 2013 & 2014 & 2013 & 2014 & 2013 & 2014 \\
\hline 16.636 & 16.948 & 1,110 & 1,114 & 15.480 & 15.826 & 1,032 & 1,040 \\
\hline
\end{tabular}

Fonte: Pesquisa ABRELPE (2014).

Tabela 6. Destinação Final de RSU na região Centro Oeste (t/dia)

\begin{tabular}{cccccc}
\hline Aterro Sanitário & \multicolumn{2}{c}{ Aterro Controlado } & \multicolumn{2}{c}{ Lixão } \\
\hline 2013 & 2014 & 2013 & 2014 & 2013 & 2014 \\
4.646 & 4.795 & 7.454 & 7.583 & 3.380 & 3.448 \\
\hline
\end{tabular}

Fonte: Adaptado ABRELPE (2014).

Em relação a destinação final, uma comparação entre os dados relativos à destinação adequada de RSU revelou discreta evolução de 2013 para 2014 na região (Tabela 6). Dos resíduos coletados na região, cerca de $70 \%$, correspondentes a 11.031 toneladas diárias, ainda são destinados para lixões e aterros controlados que, do ponto de vista ambiental, pouco se diferenciam dos próprios lixões, pois não possuem o conjunto de sistemas necessários para proteção do meio ambiente e da saúde pública.

Os municípios da região Centro-Oeste e o Distrito Federal aplicaram em 2014, em média, R\$ 3,13 por habitante/mês nos serviços de coleta de RSU e R \$ 3,32 por habitante/mês na prestação dos demais serviços de limpeza urbana (Tabela 7). Estes valores somados resultam em uma média mensal de $\mathrm{R} \$ 6,45$ por habitante para a realização de todos os serviços relacionados com a limpeza urbana das cidades.

A quantidade de empregos diretos gerados pelo setor de limpeza urbana nos municípios da região Centro-Oeste e o Distrito Federal em 2014 foi de 32.094 postos de trabalho. O mercado de serviços de limpeza urbana da região movimentou a quantia de $\mathrm{R} \$ 1,15$ bilhão, registrando um crescimento de 5,6\% em relação a 2013. A geração de empregos diretos e indiretos devido ao serviço de limpeza urbana, sem crescendo, empregando e gerando renda.

Tabela 7. Recursos Aplicados na Coleta de RSU e demais Serviços de Limpeza Urbana na Região Centro Oeste

\begin{tabular}{l|c|c|c|c}
\hline \multirow{2}{*}{ Tipos de Serviço } & 2013 & \multicolumn{3}{|c}{2014} \\
\cline { 2 - 3 } & $\begin{array}{c}\text { Recursos Aplicados Equival. Por } \\
\text { Habitante (R \$ milhões/ ano (R \$mês }\end{array}$ & População total & $\begin{array}{c}\text { Recursos Aplicados (R \$ } \\
\text { milhões/ano) }\end{array}$ & $\begin{array}{c}\text { Valor Equivalente por } \\
\text { habitante (R\$/mês) }\end{array}$ \\
\hline Coleta de RSU & $544 / 3,02$ & & 572 & 3,13 \\
\cline { 1 - 2 } $\begin{array}{l}\text { Demais serviços de } \\
\text { limpeza urbana }\end{array}$ & $590 / 3,28$ & 15.219 .608 & 607 & 3,32 \\
\hline
\end{tabular}

Fonte: Adaptado ABRELPE (2014) 


\section{Resíduos sólidos urbanos - estado de Goiás}

Em relação a 2014 são geradas 6.643 toneladas de resíduos em Goiás, desse montante 6.278 de toneladas são coletadas, sendo que mais de $5 \%$ não são recolhidas. Desse total $0,962 \mathrm{~kg}$ e produzido por pessoa em Goiás (Tabela 8). Analisando a destinação do lixo, mais de 55\% são destinados a aterros controlados ou lixões (Tabela 9), que não conta com um preparo do terreno, e acabam prejudicando o meio ambiente.

Tabela 8. Coleta e geração de RSU no estado de Goiás

\begin{tabular}{c|c|c|r|r|r|r|r}
\hline \multirow{2}{*}{\begin{tabular}{c} 
População Total \\
\cline { 3 - 7 }
\end{tabular}} & \multicolumn{4}{|c|}{ RSU Coletado } & \multicolumn{3}{c}{ RSU Gerado (ton/dia) } \\
\cline { 3 - 7 } 2013 & 2014 & 2013 & 2014 & 2013 & 2014 & 2013 & 2014 \\
\hline 6.434 .048 & 6.523 .222 & 0,955 & 0,962 & 6.146 & 6.278 & 6.547 & 6.643 \\
\hline
\end{tabular}

Fonte: Adaptado ABRELPE (2014) e IBGE (2014).

Tabela 9. Destinação Final de RSU no Estado de Goiás (ton/dia)

\begin{tabular}{c|c|c|c|c|c}
\hline \multicolumn{2}{l|}{} & \multicolumn{2}{|c}{ Aterro Controlado } & \multicolumn{2}{c}{ Lixão } \\
\hline 2013 & 2014 & 2013 & 2014 & 2013 & 2014 \\
\hline 2.732 & 2.817 & 1.950 & 1.965 & 1.464 & 1.496 \\
\hline
\end{tabular}

Fonte: Adaptado ABRELPE (2014).

\section{Caracterização do município de Jussara}

Em busca de terras férteis em 1945 as famílias de: Estevam Fernandes Rebouças, Limírio Neves da Mota, Dionísio Candido da Silva e Antônio Alves de Brito, as margens do rio Água Limpa, fundaram a região com o nome de Colônia da Água Limpa, nome devido a limpidez das águas do ribeirão.

O pequeno povoado aos poucos foi expandindo devido as terras férteis e características climáticas favoráveis, e em 1950 por sugestão de Orozimbo Coimbra Bueno, pai de Jerônimo Coimbra Bueno, então governador de Goiás resolveram fazer uma homenagem a primeira goiana eleita Miss Brasil, à Jussara Marques de Amorim, desde então seu nome foi alterado de Colônia da Água Limpa para Jussara.

No dia 12 de novembro de 1953, o povoado foi elevado à condição de distrito concedida pela Câmara Municipal de Goiás Lei Municipal 138. Em 14 de novembro de 1958 tornou-se município através da lei Estadual $n^{\circ} 2116$, e no dia 02 de maio de 1965 foi elevada à categoria de comarca, se tornando um município autônomo.

O município de Jussara está localizado a Noroeste do Estado de Goiás, na microrregião do Rio Vermelho. O referido município possui uma área territorial de $4.084,114 \mathrm{~km}^{2}$, e uma densidade demográfica de 4,69 hab/ $\mathrm{km}^{2}$. Com uma população em 2010 de 19.153 (dezenove mil cento e cinquenta e três) habitantes, e segundo estimativas do IBGE, e que sua população em 2016 seja de 19.292 (dezenove mil duzentos e noventa e dois) habitantes. E por fim está a 220 km da capital Goiânia e a 415 km da capital federal Brasília.

\section{Estudo de campo}

Caracterização do passivo ambiental gerado pelo Lixão em Jussara/Goiás. O consumo é essencial para a sobrevivência das espécies. Os animais contentam-se com o básico, os alimentos da mãe natureza são suficientes para sua subsistência, já para os seres humanos, sua sobrevivência consiste em extrair matéria prima da natureza e transformar em bens de uso e consumo para ser revendido pela sociedade.

A extração dos recursos naturais e despejo inadequado das sobras e do que não pode ser mais utilizado, de uma forma descontrolada acarreta diversos problemas ambientais, sociais e econômicos. Com o aumento do consumo, consequentemente eleva o descarte de bens considerados inservíveis, conhecidos como resíduos. Onde descartados de forma inadequada, contaminam o ar, solo, água e propagam diversas doenças dentre vários problemas a sociedade.

O município de Jussara, estado de Goiás ainda não conta com um aterro sanitário, nem coleta seletiva, para separar os resíduos que podem ser reaproveitados e designar apenas os rejeitos ao aterro. Sem local propício para destinação do lixo, o poder público recolhe o lixo da cidade e deposita 
tudo em um lixão, local sem nem um preparo ambiental, para vedação do solo, sendo o mesmo sujeito aos diversos resíduos ali depositados, podendo contaminar o solo, $\mathrm{o}$ ar e o lençol freático que se encontra a algumas camadas do solo.

Em busca de demonstrar o problema ocasionado pelo descarte de resíduos, foi realizada uma visita no local onde é o lixão da cidade.

\section{Material e Métodos}

Segundo dados do Sistema Nacional de Informações sobre saneamento (SNIS) o lixão do município de Jussara teve início em suas operações no ano de 1988, não possui licença ambiental para operacionalização. O lixão de Jussara recebe 6.683 toneladas/ano de lixo, sendo 5.328 domésticos e públicos, 1.320 de entulho e 35 de podas.

A Lei 12.305 estabelecia um prazo de quatro anos para as prefeituras se adequarem a lei, sendo que esse prazo venceu em 2014, desde então diversos municípios ainda não conseguiram se adequar a referida lei. Não diferente de vários municípios goianos, Jussara ainda deposita seus resíduos em um local improprio, sem a coleta seletiva que minimizaria a quantidade de resíduos depositados no lixão.

No dia 09 de setembro de 2016 foi realizada uma visita no local onde se encontra o lixão da cidade de Jussara, é impressionante a quantidade de lixo que está depositada no local. No dia 15 de fevereiro de 2016 a prefeitura publicou em seu site oficial o combate ao Aedes Aegypti, realizando a limpeza de ruas e terrenos para diminuir os objetos onde o mosquito transmissor da dengue possa se proliferar. Essa limpeza acumulou uma grande quantidade de resíduos, aumentando ainda mais a quantidade de lixo depositado no lixão da cidade.

Para acomodar o lixo, foram enviadas maquinas ao local, para melhor comportar todo o lixo que já havia no local, com o lixo que estava sendo recolhido no combate ao Aedes Aegypt.Mesmo com uma ação promovida pela prefeitura do município no início do ano, ainda há muito lixo no local, situação que preocupa, tanto no ponto de vista ambiental, quanto para a saúde pública. Foram tiradas fotos no local nas quais se pode observar a gravidade do problema.

\section{Penalidades da não adequação à Lei 12.305/10}

Segundo a lei dos crimes ambientais, decreto 6.514/08 em seu art. 61, quem causar poluição ao meio ambiente, que possa resultar em danos à saúde humana, destruição da biodiversidade, ou a morte de animais, devido à disposição inadequada dos resíduos, estará sujeito à multa de $\mathrm{R} \$ 5$ mil a $\mathrm{R} \$ 50$ milhões.

A crescente montanha de lixo se espalha pela paisagem do local, uma mistura de "lixo novo" recém-descarregado do caminhão, e o "lixo velho" que já está queimado e amassado pelo trafego dos caminhões.

Observando a Foto 1, do lado esquerdo da imagem, é possível notar que há restos de construção, como gesso quebrado, restos de cimento. No centro da imagem há diversos materiais, como caixas de papelão, plásticos, como garrafas pets (materiais esses que se houvesse a coleta seletiva poderiam ser reaproveitados pela indústria). Do lado direto estão diversos galhos de árvores, provenientes das podas da cidade. Ao fundo, os materiais que já foram depositados em outros períodos.

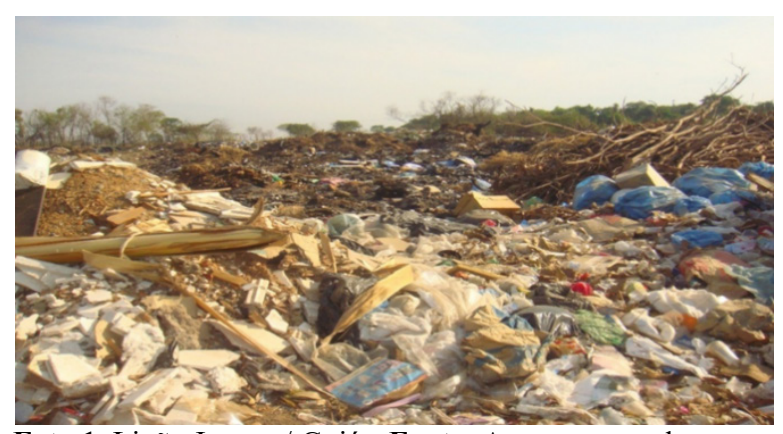

Foto 1. Lixão Jussara/ Goiás. Fonte: Acervo pessoal.

Sem opção e largados a própria sorte, diversos animais domésticos como: cães e gatos são soltos nas proximidades do local (Foto 2 ). Sem opção e em busca da sobrevivência, esses animais vão vivendo de restos de animais ali descartados. Em busca de alimentos os urubus, também dividem o espaço, devido a abundância de alimentos em decomposição. Esses animais que por ali transitam, estão sujeitos a qualquer tipo de doença e contaminação.

As Fotos 3 e 4 mostra o descarte de animais mortos. E em busca de alimentos, os urubus se concentram nesses locais, os restos de animais poderiam ser incrementados do processo de compostagem. Como melhor exemplificado por Paiva (2006), a compostagem e o método correto para a destinação dos restos de animais mortos, sendo a melhor alternativa para os criadores, pois apesar de sua execução ter que atender critérios rígidos, se utiliza pouca mão de obra. 


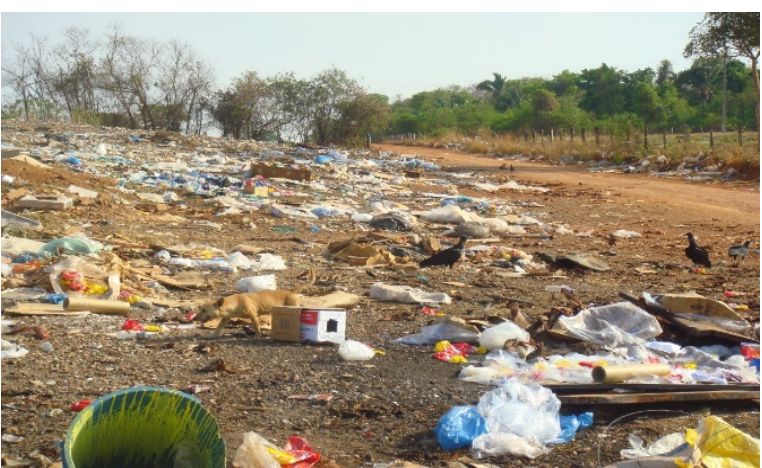

Foto 2. Animais junto ao lixo. Fonte: Acervo pessoal.

A compostagem conduzida corretamente evita a contaminação dos recursos hídricos, ar ou o solo, fornecendo ao final do processo, um composto orgânico rico em nutrientes, excelente para ser utilizado no solo. Os restos de animais quando descartados no meio ambiente sem um tratamento pode contaminar o solo e o lençol freático prejudicando o meio ambiente, já quando há uma destinação correta esses restos de animais podem virar um composto orgânico, rico em nutrientes úteis nas lavouras.

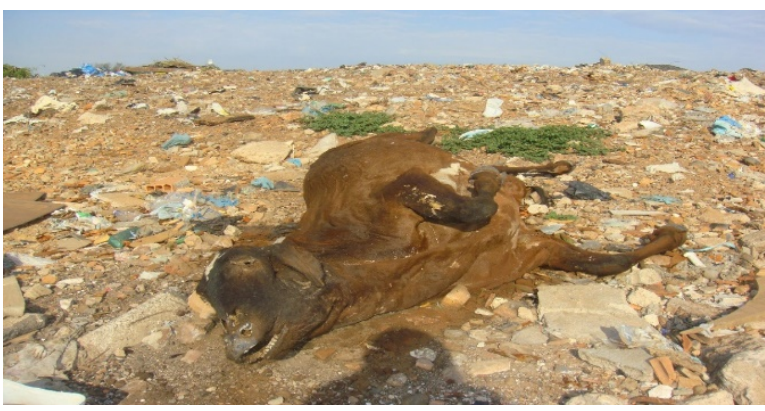

Foto 3. Animais em decomposição. Fonte: Acervo pessoal.

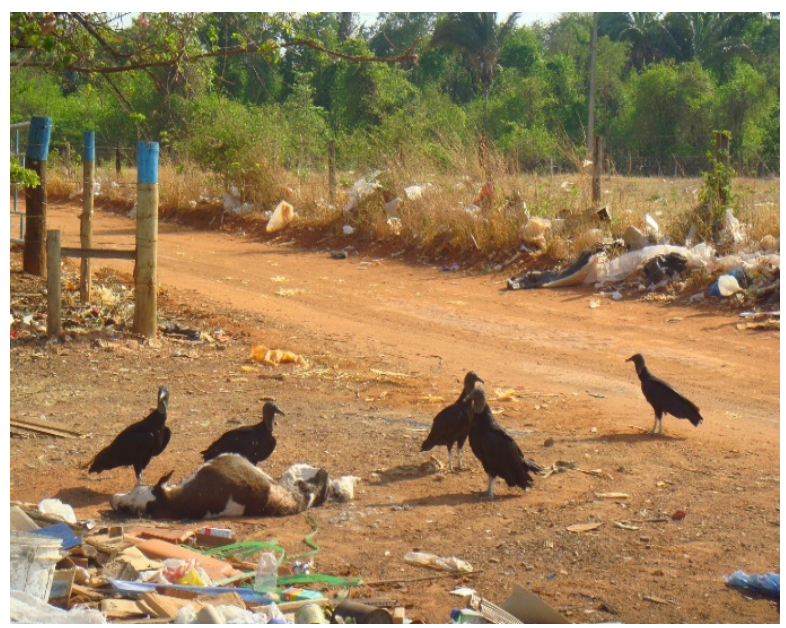

Foto 4. Urubus. Fonte: Acervo pessoal.

Também foram encontradas várias garrafas de vidro que representam um passivo ambiental com um tempo indeterminado para sua decomposição, prejudicando o meio onde ele será depositado. Por isso a importância de repensar é introduzi-lo a cadeia produtiva, aumentando o ciclo de vida. Dentre as várias garrafas de vidro encontradas no local (Foto 5), essas em especial chamam a atenção, pois são garrafas de cerveja, que deveriam retornar a industrial para serem reaproveitadas e novamente serem vendidas. A lei 12.305 art. $30^{\circ}$ inciso II, diz para "promover o aproveitamento de resíduos sólidos, direcionandoos para a sua cadeia produtiva ou para outras cadeias produtivas". A indústria de cervejaria, já implantou em seu processo o retorno das garrafas para serem novamente utilizadas.

Os comerciantes pagam a diferença para os fornecedores caso não tenha os cascos das garrafas para fazer o retorno. O que vemos é a falta de consciência da população, que por falta de interesse ou até mesmo de conhecimento, não dão importância aos problemas que o lixo causa ao meio ambiente. Mesmo não podendo ser descartados no meio ambiente, embalagens com produtos tóxicos são encontrados em grande quantidade.

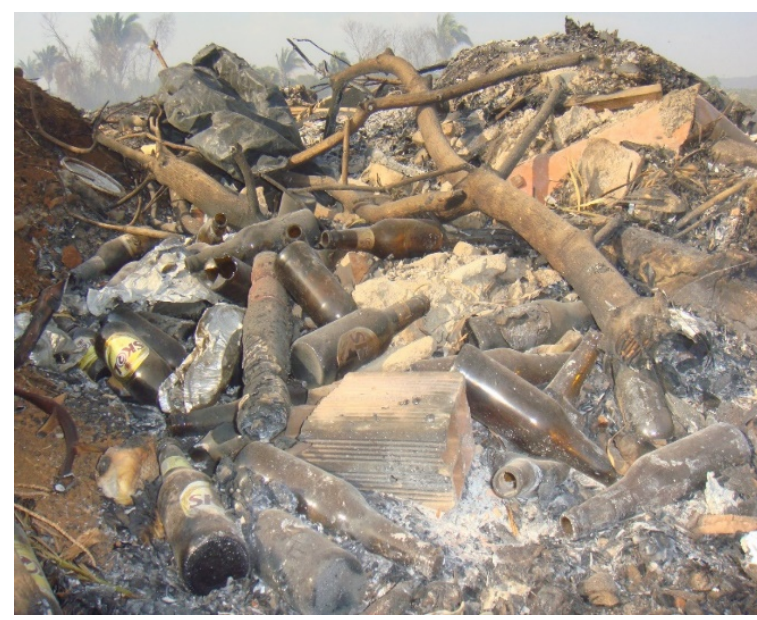

Foto 5 - Garrafas de vidro. Fonte: Acervo pessoal.

A Lei 12.305 em seu artigo Art. 33 estabelece a implantação do sistema de logística reversa, para fabricantes, importadores, distribuidores e comerciantes, retornarem os produtos após o uso dos consumidores, não dependendo do serviço público, os seguintes produtos: I - Agrotóxicos, e outros produtos cujos resíduos constitua risco ao meio ambiente; II - baterias e pilhas; III pneus; IV - embalagens e resíduos de óleos lubrificantes; V - Lâmpadas fluorescentes e VI eletroeletrônicos e seus componentes.

Todos esses produtos da Foto 7, independente do serviço público, após o uso pelos consumidores deveriam retornar aos fabricantes, importadores, 
distribuidores ou comerciantes, para receberem uma destinação correta, e não prejudicar o meio ambiente.

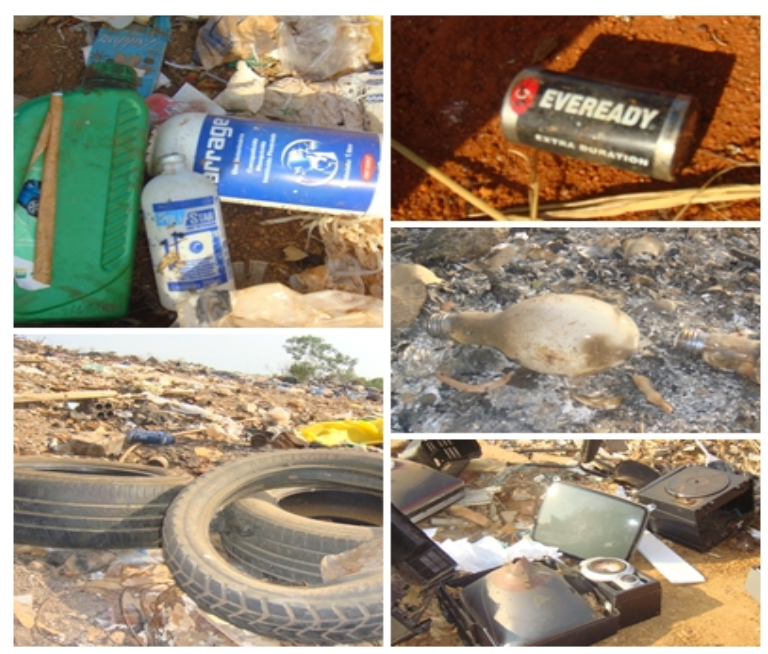

Foto 7. Produtos da logística reversa. Fonte: Acervo pessoal.

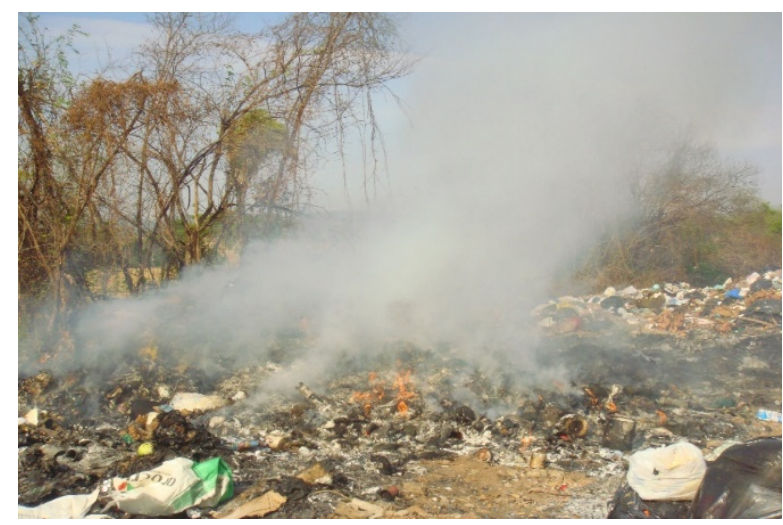

Foto 8. Queima do lixo. Fonte: Acervo pessoal.

Após ser depositado, o lixo é queimado, trazendo pela fumaça a contaminação do ar, que pode se espalhar por quilômetros. Sem o devido tratamento, o acúmulo de lixo com disposição em locais impróprios traz consequências à sociedade como contaminação do solo, água e ar, facilita a proliferação de animais transmissores de doenças, dentre diversos outros problemas ambientais e sociais.

\section{Conclusões}

O homem extrai da natureza os recursos naturais para suprir a necessidade da sociedade e com o aumento da população essa extração aumenta a cada dia, consequentemente cresce o descarte dos materiais considerados inservíveis à sociedade.

O município de Jussara, não conta com um aterro sanitário, nem coleta seletiva. Desde o ano de 1988, 6.683 toneladas de lixo por ano são depositados no lixão da cidade, local impróprio sem a devida vedação e preparação do solo, contaminando o solo, ar, lençol freático e até animais que por ali trafegarem.

No dia 09 de setembro de 2016, por meio da pesquisa realizada no local do lixão da cidade, demonstrou diversos materiais como caixas de papelão, plásticos, garrafas pets, e diversas garrafas de vidro, (as garrafas de vidro são um passivo ambiental, que sua decomposição leva milhares de anos) materiais que poderiam ser reintegrados no processo de industrialização, aumentando o ciclo de vida dos materiais, se houvesse a coleta seletiva no município.

As imagens da pesquisa também mostram diversos animais em decomposição, restos que no processo de compostagem destina os restos de animais mortos, evitando a contaminação do solo, ar e recursos hídricos, tendo no final do processo da compostagem um composto orgânico rico em nutrientes, de grande valor para o solo.

Materiais como lâmpadas fluorescentes, pilhas, baterias, embalagens de agrotóxicos, embalagens de óleos, eletroeletrônicos e pneus, não são responsabilidade do poder público, é sim dos fabricantes, importadores, distribuidores e comerciantes, a retornarem esses produtos a empresas que destinem esses materiais a locais corretos não prejudicando o meio ambiente.

A conscientização deveria ser maior por parte do consumidor, pois esses materiais têm um autopoder de prejudicar o meio onde ele é descartado, e a população o descarta de forma irresponsável, sem pensar no meio ambiente causando maior impacto as futuras gerações. Por meio da pesquisa, foi possível perceber que os passivos ambientais oriundos da disposição do lixo em locais sem a devida preparação do solo, acarretam diversos problemas ambientais e sociais. O passivo ambiental representa danos causados ao meio ambiente, à constatação desse passivo se faz necessário para avaliar a situação ambiental daquela região.

\section{Referências Bibliográficas}

ABRELPE. 2014. Associação Brasileira de Empresas de Limpeza Pública e Resíduos Especiais. ABRELPE.

Araújo, S. A. P., Costa, S.T.F., Silva, K.N., Mendes, J. J., Paulo, N. R. \& Brito, D. A. A. 2016. A Gestão Sustentável em Restaurantes e Lanchonetes: estudo de caso na cidade de Jussara/GO no exercício de 2014. In. Caetano, 
G. A. O.; Cintra, D. G. B. Contabilidade ambiental e relatórios socioambientais. Goiânia/GO: Kelps, 219p.

BRASIL Lei $\mathrm{N}^{\circ}$ 12.305. 2 ago. 2010. Política Nacional de Resíduos Sólidos Disponível em: $<$ http://www.planalto.gov.br/ccivil_03/_A to2007-2010/2010/Lei/L12305.htm> Acesso em: 06 ago. 2016.

. Lei $\mathrm{N}^{0}$ 9.605. 12 fev. 1998. Lei dos crimes ambientais. Disponível em: $<$ http://www.planalto.gov.br/ccivil 03/leis /L9605.htm> Acesso em: 06 ago. 2016.

Decreto No6.514. 22 jul de 2008. Infrações e Sanções administrativas ao meio ambiente.

Disponível em:<http://www.planalto.gov.br/ccivil 03/ at o2007-2010/2008/decreto/d6514.htm> Acesso em: 10 nov. 2016

. Constituição Federal (1988). Capítulo VI do meio ambiente. Artigo 225. Disponível em:

$<$ http://www.planalto.gov.br/ccivil_03/constit uicao/constituicaocompilado.htm>. Acesso em: 06 out. 2016.

Constituição (1988). Emenda constitucional no 9 , de 9 de novembro de 1995. Dá nova redação ao art. 177 da Constituição Federal, alterando e inserindo parágrafos. Lex: legislação federal e marginália, São Paulo/SP, v. 59, p. 1966, out./dez. 1995.

Lei $\mathrm{N}^{\circ}$ 6.938. 31 ago. 1981. Política Nacional do Meio Ambiente. Disponível em:<http://www.planalto.gov.br/ccivil 03/leis /L6938.htm> Acesso em: 22 set. 2016.

Costa, C. A. G. 2012. Contabilidade ambiental: mensuração, evidenciação e transparência. Atlas,São Paulo.

Dias, R. 2014. Eco-inovação: caminho para o crescimento sustentável. Atlas,São Paulo.

Dinis, Fernanda. 2016. Controle biológico: ciência a serviço da sustentabilidade. EMBRAPA.

Fiorillo, C. A. P. 2009. Curso de direito ambiental brasileiro. Saraiva,São Paulo.

IBGE, Censo demográfico 1960, 1970, 1980, 1991, 2000 e 2010. Disponível em: $<$ http://www.censo2010.ibge.gov.br/sinopse/i ndex.php?dados=8> Acesso em: 07 ago. 2016.

Iudícibus, S. 1998. Análise de balanços: análise da liquidez e do endividamento; análise do giro, rentabilidade e alavancagem financeira. Atlas,São Paulo.
Machado, P. A. L. 2014. Direito ambiental brasileiro. Ed. Revista dos Tribunais,São Paulo.

Malafaia, R. M. S. 2004. Passivo ambiental: mensuração, responsabilidade, evidenciação e obras rodoviárias, Rio de Janeiro.

Paiva, P. R. 2006. Contabilidade ambiental: evidenciação dos gastos ambientais com transparência e focada na prevenção. Atlas,São Paulo.

Prefeitura de Jussara. Máquinas fazem manutenção no lixão. 2016. Disponível em: $<$ http://noticiasdejussara.blogspot.com.br/201 6/02/jussara-maquinas-fazem-manutencaono.html> Acesso em: 11 set. 2016.

Prefeitura De Jussara. História. Disponível em: $<$ http://jussara.go.gov.br/?page_id=16> Acesso em: 11 set. 2016.

Ribeiro, M. S. 2006. Contabilidade ambiental. Saraiva,São Paulo.

Santos, A. d. O., Silva, F. B., Souza, S. \& Sousa, M. F. R. 2001. Contabilidade ambiental: um estudo sobre sua aplicabilidade em empresas brasileiras. Revista Contabilidade \& Finanças, 12, 89-99.

Sistema Nacional de Informações sobre Saneamento SNIS - Resíduos Sólidos: fluxo e quantidade de resíduos, ano de referência: 2014, Região: Centro oeste, Estado: Goiás, município de origem: Jussara/GO, Unidades: Jussara-Lixão de Jussara/Go/GO[5212204000]. Disponível em: $<$ http://app.cidades.gov.br/serieHistorica/\#>A cesso em: 10 set. 2016.

Souza, D. C. 2010. O meio ambiente das cidades. Atlas,São Paulo.

Tinoco, J. E. P. \& Kraemer, M. E. P. 2004. Contabilidade e gestão ambiental. Atlas,São Paulo.

\section{Article History:}

Received 25 February 2017

Accepted 27 March 2017

Available on line 4 May 2017

License information: This is an open-access article distributed under the terms of the Creative Commons Attribution License 4.0, which permits unrestricted use, distribution, and reproduction in any medium, provided the original work is properly cited. 